\title{
GEORGE POULETT-SCROPE, F.R.S., F.G.S. ${ }^{1}$
}

\author{
Born, 10 March, 1797. Died, 19 January, 1876.
}

ONe by one, the last few strands are being severed, which connected the younger school of Geologists with the early masters of their science, whose large and comprehensive views tended so much to render Geology what it now undoubtedly is, the most popular science of the day. Those who had the good fortune to know Mr. Poulett Scrope personally, as a scientific man, were few, but they can testify to the broadness of his scientific views, as well as to the nobleness of his character. Those who knew him by his published works (on 'Volcanos,' etc.) were many, and none can doubt the wide influence of his writings on the current of geological thought to-day.

Many of the most advanced propositions in geology may be traced back in time to Mr. Poulett Scrope's earlier works.

Thus, for example: That the foliation in metamorphic schists, no less than the cleavage of the finer slate-rocks, was due to the squeezing of their crystalline or semi-crystalline particles while in a viscous state ('Volcanos,' 1825). ${ }^{2}$

That most valleys are due to subaerial denudation ('Geology and Volcanos of Central France,' 1827). ${ }^{3}$

'That many deposits, hitherto referred to different geological ages, may have been accumulated contemporaneously in contiguous areas ('Volcanos,' 1825, p. 239).

That volcanic cones are not due to the blister-like elevation of the superjacent strata, as advocated by Humboldt, von Buch, and Elie de Beaumont; but to the accumulation, above the fissure or vent, of ejected materials, as ashes, cinders, scoriæ, pumice, and other loose materials interstratified with beds of lava. ${ }^{4}$

That steam is the great dynamical agent in all volcanic outbursts; and that it also fills the interstices of all fluid lavas.

As an old Member of Parliament from 1833-1868 (a period of thirty-five years), Mr. Scrope was personally known to many, and sincerely esteemed by all his colleagues on the Liberal benches.

To the pages of this Magazine he has been a frequent contributor up to the last.

1 [A full notice of Mr. Poulett Scrope, with a Portrait, will be found in the Geor. Mag. 1870, Vol. VII. p. 193.] See also notices in the 'Academy,' 'Nature' and the 'Athenæum,' for 29 January, 1876.

2 'Geologist,' 1858, vol. i. p. 362 .

3 Geol. Mag. 1866, Fol. III. p. 193.

- 'Volcanos,' 1825; Quart. Journ. Geol. Soc. 1856, p. 337. 